\title{
Automated Sanitizing Tunnel
}

\section{Túnel Sanitizante automatizado}

GONZALEZ-MONZON, Ana Lilia $\dagger^{*}$, RUEDA-MEDINA, Israel, PACHECO-ALVARADO, Luis Kevin and MARTINEZ-SANTIAGO, Alejandro

\section{Tecnológico Nacional de México/ Tecnológico de Estudios Superiores de Jilotepec}

ID $1^{\text {st }}$ Author: Ana Lilia, González-Monzón / ORC ID: 0000-0002-0280-0525, CVU CONACYT ID: 151293

ID $1^{\text {st }}$ Co-author: Israel, Rueda-Medina / ORC ID: 0000-0003-0405-0913, CVU CONACYT ID: 153741

ID $2^{\text {nd }}$ Co-author: Luis Kevin, Pacheco-Alvarado / ORC ID: 0000-0001-5845-4150, CVU CONACYT ID: 883154

ID $3^{\text {rd }}$ Co-author: Alejandro, Martínez-Santiago / ORC ID: 0000-0003-4695-358X

DOI: $10.35429 /$ JID.2021.13.5.22.26

Received July 23, 2021; Accepted October 30, 2021

\begin{abstract}
Currently COVID 19 is a contagious virus that affects in different ways depending on each person, most of the people who are infected have symptoms of mild or moderate or very high intensity because in such a short time thousands of people are infected by contact being in a single area, the objective is to make an automated sanitizing tunnel in the Tecnológico de Estudios Superiores de Jilotepec so that students, teachers and staff entering the tunnel are sprayed with a disinfectant substance that will cover the entire body including hands as well as shoes and thus minimize the possibility of contagion; This is considered in the interest of the application of useful measures for the prevention of the contagion of the virus when entering the institution since this will avoid if bringing the virus in clothing, hair, face, hands, shoes. be neutralized by contact with the disinfecting substance.
\end{abstract}

Automated, Sanitizing, Covid

\begin{abstract}
Resumen
En la actualidad el COVID 19 es un virus contagioso que afecta de distintas maneras en función de cada persona la mayoría de las personas que se contagian presentan síntomas de intensidad leve o moderada o muy alta debido a que en tan poco tiempo se contagian miles de personas por contacto estando en una sola área, el objetivo es realizar un túnel sanitizante automatizado en el Tecnológico de Estudios Superiores de Jilotepec para que los alumnos, docentes y personal que ingresen al túnel y sean roseados de una sustancia desinfectante que cubrirá todo el cuerpo incluyendo manos a si como los zapatos y así minimizar la posibilidad de contagio; esto es considerado en el interés de la aplicación de medidas de utilidad para la prevención del contagio del virus al ingresar a la institución ya que esto evitara si al traer el virus en la ropa, cabello, cara, manos, zapatos .ser neutralizado al tener contacto con la sustancia de desinfección.
\end{abstract}

Automatizado, Sanitizante, Covid

Citation: GONZALEZ-MONZON, Ana Lilia, RUEDA-MEDINA, Israel, PACHECO-ALVARADO, Luis Kevin and MARTINEZ-SANTIAGO, Alejandro. Automated Sanitizing Tunnel. Journal Innovative Design. 2021, 5-13: 22-26

\footnotetext{
*Correspondence to the Author (e-mail: ana.gm@jilotepec.tecnm.mx)

$\uparrow$ Researcher contributing as first author.
} 


\section{Introduction}

The covid 19 has been a big problem, in this stage of virus, we know that it can be carried in clothes, hair, shoes or items that we can bring for personal use so a Sanitizing Tunnel at the entrance of the Tecnológico de Estudios superiores de Jilotepec is very important because when entering the institution, all students and teaching and administrative staff may pass to sanitize and thus minimize the contagion in case someone could carry the virus in the objects already mentioned, considering that it is automatically.

In section number one we find the introduction where it shows the content of all the writing, in section number two the materials used for the conformation of the prototype, in number three we find the electronic design that is the main base of the main prototype, in number four the methodology develops the steps with which it was carried out, in number four the development of the methodology where it shows how the tunnel was assembled and the sixth shows the results obtained from the project.

\section{Development}

Acrylic: Acrylic is a transparent or pigmented thermoplastic polymer with a wide range of colors. It is obtained from the polymerization of methacrylate monomer and is melted to offer it in sheets of standard sizes. Acrylic is one of the most consumed plastic materials as it is mainly used in: architecture, optics, construction, advertising, decoration, exhibition, printing, engineering applications, graphic arts and plastic arts.

A sprinkler is a device that transforms the flow of a pressurized liquid into a spray, which is the main reason why it is frequently used for irrigation purposes. The sprinkler is the device used in parks, gardens or in places where there are lawns for watering. It is a small but powerful device that allows spraying with the right amount of moisture. (See figure 1)

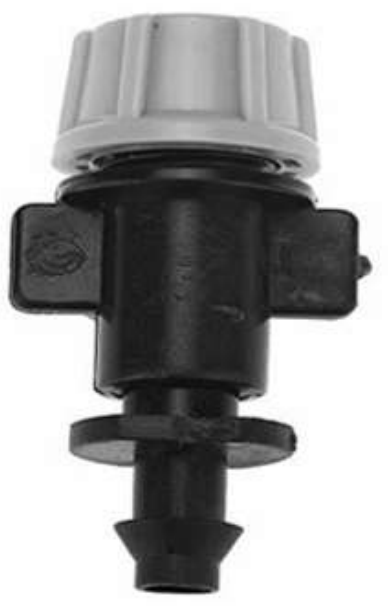

Figure 1 Sprinkler (hidroenv 2021)

Float: The float is a hermetically sealed plastic product, also known as a floating level sensor or switch, its design is very practical, as well as its installation, since it does not require major complications for its placement. In a society where drinking water is becoming increasingly scarce, the electric float is an excellent product to achieve a lower waste of water and electric energy. PanamaCOM. (2021). See Figure 2.

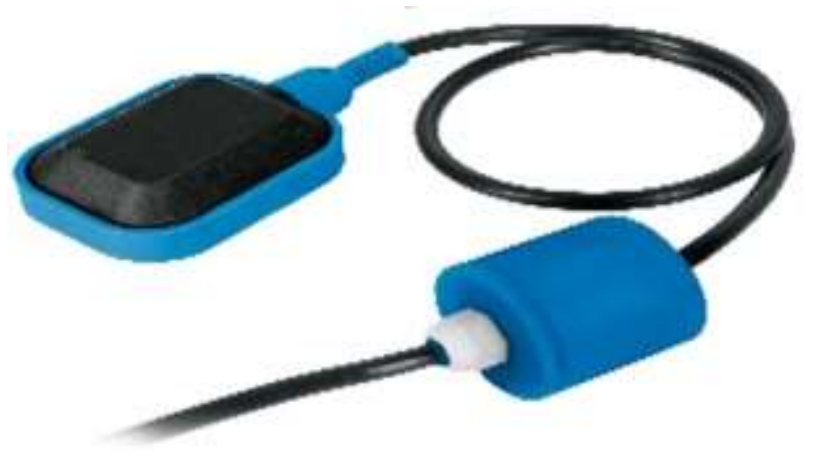

Figure 2 Floater (Panama 2021)

\section{Motion sensor}

A presence sensor or motion sensor is an electronic device that turns a system on or off when it detects motion in the area or environment in which it is installed. They are often used to optimize the energy consumption and efficiency of various systems such as ventilation, lighting or air conditioning in the home or office, although they also have applications in the field of security. (See figure 3) 


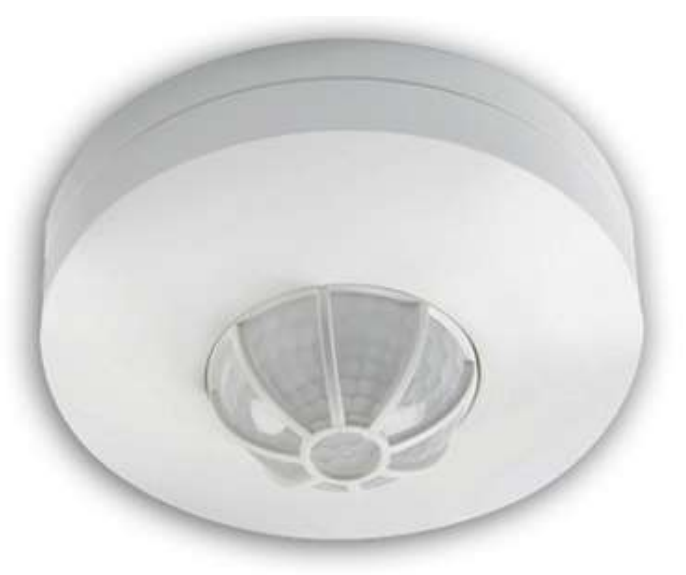

Figura 3 Sensor (Honewell 2018)

Hydraulic pump is a generating machine that transforms the energy with which it is driven into energy, which moves and increases the pressure of a fluid by adding energy to the hydraulic system, to move the fluid from a zone of lower pressure to a zone of higher pressure. See Figure 3. Pump)

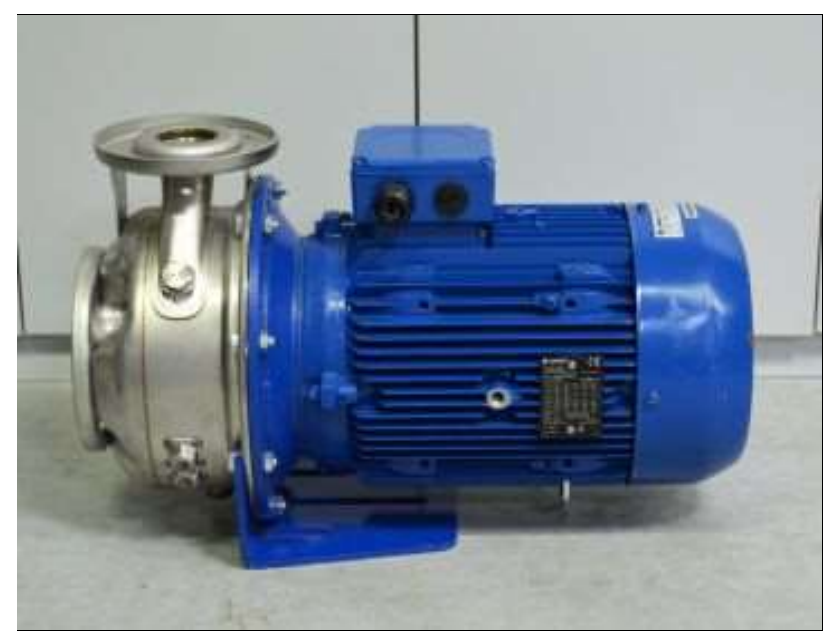

Figure 3 Pump (Hiunday 2021)

In a control system there are elements called sensors, whose function is to collect data or interpret user commands within this are the button panels that are protected operator type of basic metal material, red, lamp module voltage 24VAC / DC, Total voltage. (See Figure 4).

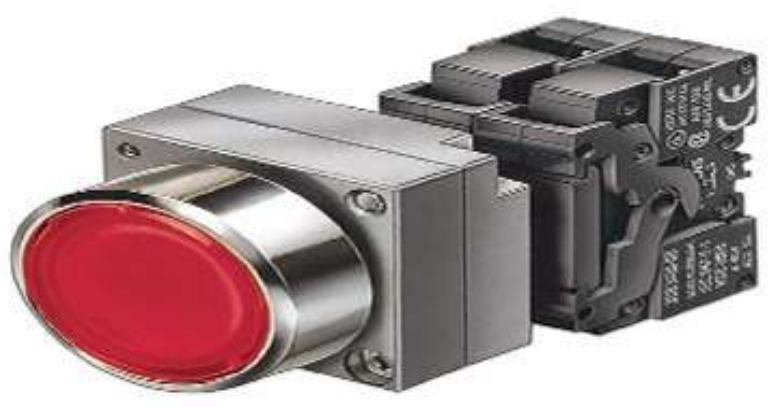

Figure 4 Pushbutton panel (Grainger 2020)
A terminal block is a type of electronic connector where a wire is clamped against a metal part by the use of a screw, without using connectors or compatibility problems in joining wires of different cross-sections with a firm contact. (See Figure 5.)

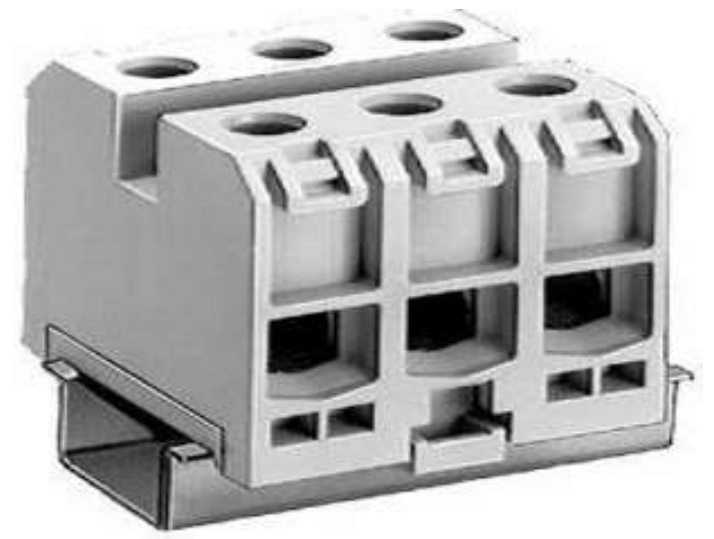

Figure 5 Clema (Grainger 2020)

\section{Design}

Electrical diagram that includes the connection of the elements of the button box, where it shows the single-phase electrical connection where it shows, the manual mode in the first line the start button that actuate it passes the current and it goes to the motor guard drives the green start lamp following the next one the stop button stops by the contactor and the second red lamp lights, then appears the automatic mode that when it detects the sensor does its function passing through the motor guard and the contactor lighting the lamps. (See Figure 6).

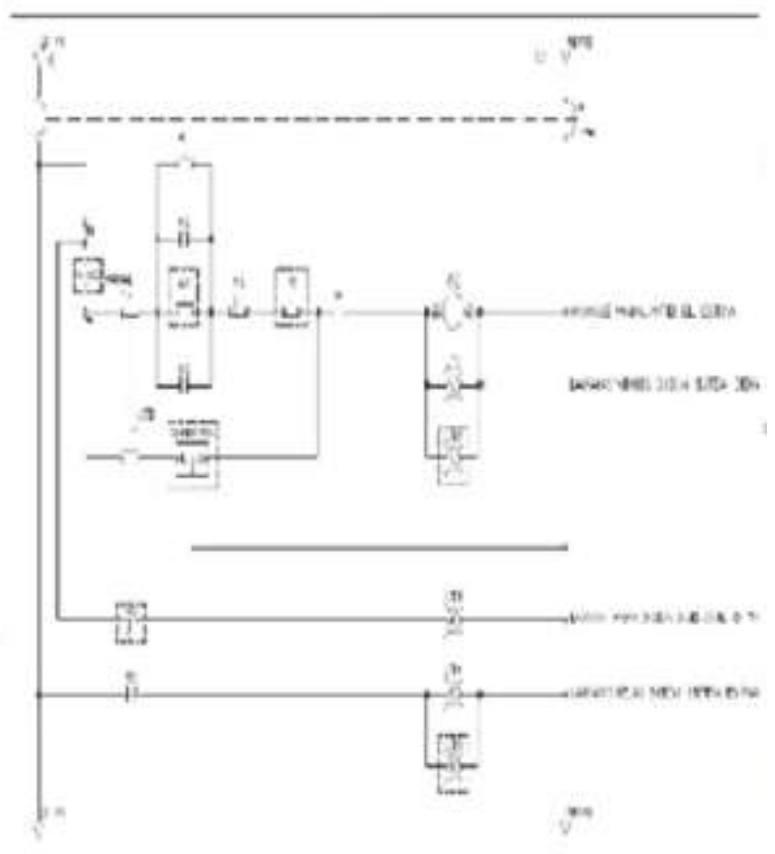

Figure 6 Electrical diagram Source: Own Elaboration

GONZALEZ-MONZON, Ana Lilia, RUEDA-MEDINA, Israel, PACHECO-ALVARADO, Luis Kevin and MARTINEZ-SANTIAGO, Alejandro. Automated Sanitizing Tunnel. Journal Innovative Design. 2021 


\section{Methodology to be developed}

Conception: To make the sanitizing tunnel it is necessary to investigate other research works about the tunnels and to gather the necessary information to make then we have a protocol of what has to be done according to the information gathered and the necessary materials.

Design: For the operation of the tunnel an electrical diagram will be made showing how it will work in manual and auto mode as well as a schedule of activities to take into account what will be done in each month and thus keep track.

Implementation: Having the electrical design, the materials, we will begin to structure the sanitizing tunnel in the best way that people can enter without any problem.

Operational: After having the structure with all its components incorporated, we will test the operation of the tunnel and if we obtain the results we expect, it will be placed in the area established for its use.

Give the meaning of the variables in linear wording and it is important to compare the criteria used.

\section{Results}

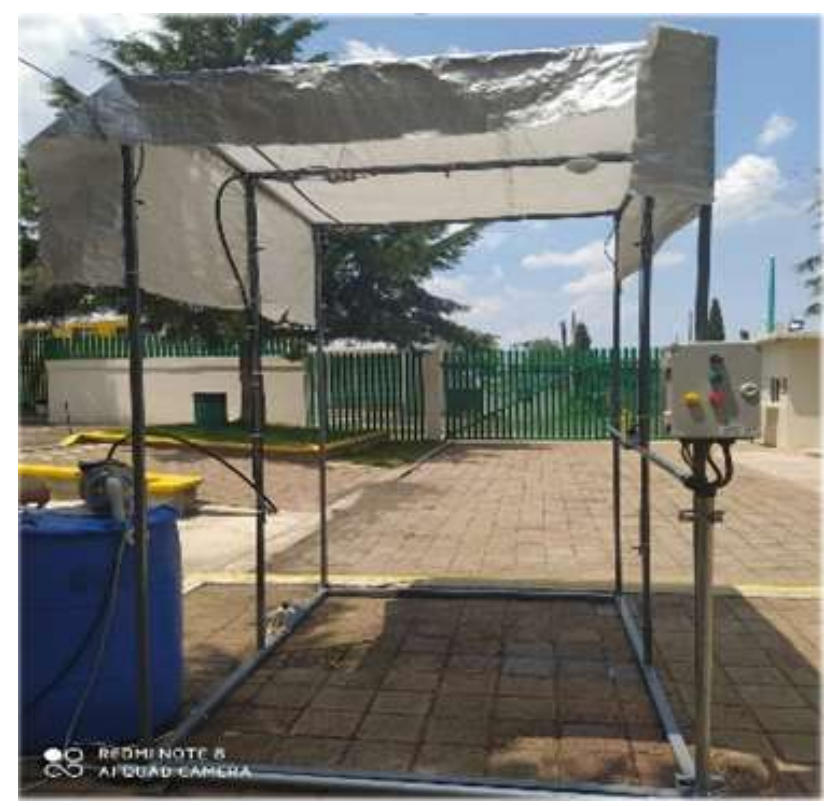

Figure 7 Structure

Source: Own Elaboration
In this part the structure of the tunnel that is made by ptr as a structure for the placement of the sprinklers that are activated by the sensor, has a float that is permissive and helps to deactivate the system automatically if the drum is emptied. (See Figure 8).

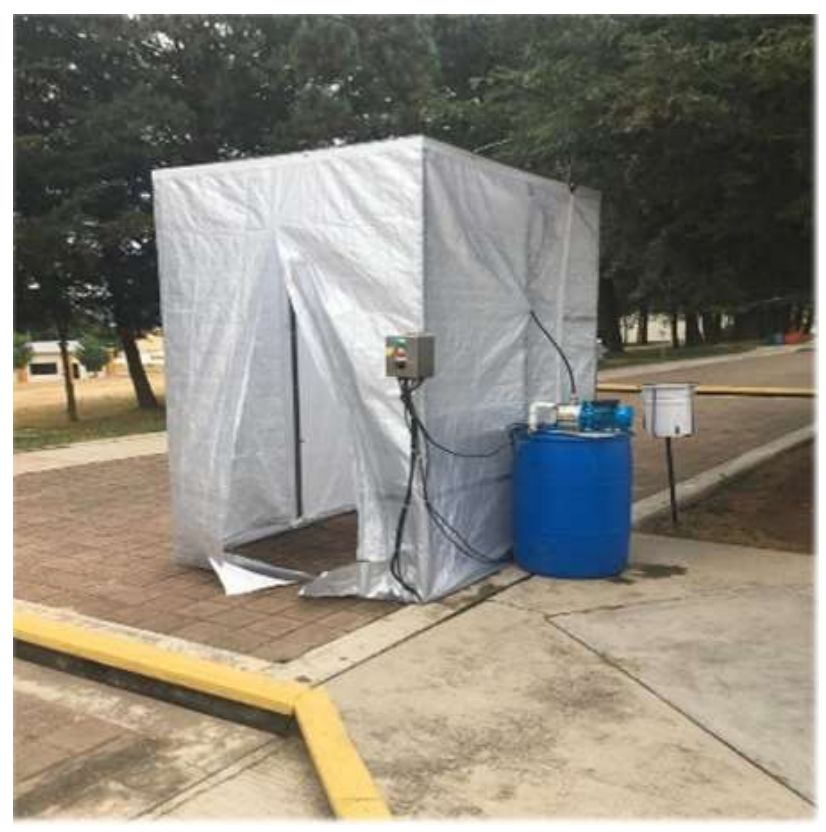

Figure 8 Automated Sanitizing Tunnel Source: Own Elaboration

In this part is the tunnel finished with the elements in such a way that it is combined for the control of the system, both manual and automatic by means of a switch that allows the two functions and in the same way it protects from a short circuit, by means of a permissive transmitter of starting, by means of a sensor that allows to detect the movement and to be activated. The cost of the prototype is considered competitive in contrast to what is on the market, ranging between $\$ 12,000.00$ for material and labor, being a project of constant utility to reduce the spread of Covid-19.

\section{Conclusions}

The disinfectant tunnel in these times of pandemic is a project that allows to carry out prevention in the part of disinfection of all persons entering the Tecnologico De Estudios Superiores de Jilotepec and can reduce the possibility of contagion by being sprayed with sanitizer from the head, clothes, backpack, shoes considering that the virus can be transported by these routes and thus avoid possible contagion of covid-19. 


\section{Acknowledgement}

We thank the Tecnológico de Estudios Superiores de Jilotepec for their support.

\section{References}

Pallas R. (2020). Sensores y Acondicionadores de Señal. Barcelona, España: Marcombo.

Rodríguez P. C (2019). Componentes electrónicos. México: Biblioteca electrónica.

Prat V. LI. (2017) Circuitos y dispositivos electrónicos, México: Alfaomega.

Ballester E. Pique. R (2019) Electrónica de potencia México, Alfaomega

Reyes Ayala, J. E., \& Flores Pérez, J. L. (2016). Proyecto sensor de movimiento.

OMS, O. (11 de Marzo de 2020). Brote de enfermedad por coronavirus (COVID-19). Obtenido de Nuevo Coronavirus 2019: https://www.who.int/es/emergencies/diseases/n ovel-coronavirus-2019/advice-for-public/q-acoronaviruses

Pérez, J. L. (25 de Marzo de 2018). Proyecto sensor de movimiento. Obtenido de instituto Tecnologico del Parral 